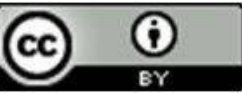

\title{
MAJOR BEHAVIORAL RISK FACTORS FOR ROAD TRAFFIC INJURIES
}

\author{
Svetlana COCIU1 ${ }^{1}$, Olga IONCU ${ }^{1}$, Camelia CAZACU-STRATU1 ${ }^{1}$, Serghei CEBANU ${ }^{1}$, Cara HAMANN² \\ ${ }^{1}$ Nicolae Testemitanu State University of Medicine and Pharmacy, Chisinau, Republic of Moldova \\ ${ }^{2}$ College of Public Health, the University of Iowa, United States
}

Corresponding author: Svetlana Cociu, e-mail: svetlana.cociu@usmf.md

DOI: $10.38045 /$ ohrm.2021.4.02

CZU: 614.8:656.1

Keywords: motor Introduction. Road traffic injuries are a major public health problem, ranking $8^{\text {th }}$ in the vehicle injuries, risk factors, car accident, prevention. leading causes of death and are forecasted to rank $5^{\text {th }}$ by 2030 worldwide. Children, pedestrians, cyclists and the elderly remain among those most at risk of road traffic injuries.

Material and methods. A specialized literature search was conducted within the main international databases, including: PubMed/MEDLINE, Google Scholar, and Research Gate, using a set of inclusion criteria. Data from references were extracted systematically into results tables, including: author/citation, study design, assessments/data, limitations, and key facts. Reported outcomes were compiled in narrative form.

Results. Many researchers and scientists both in the country and abroad have studied road injuries. Authors of the studies used different methods and obtained obvious data about road traumas and major risk factors. Among the main causes of unintentional motor vehicle injuries were excessive speed, alcohol consumption while driving, mental disorder, drugs, and unsupervised children. There is an increasing incidence of road injuries among children, and most of the road traffic crashes involving children occur in May-September, between 11.00 and 18.00. The obtained results motivate the need to study this topic in depth, on separate age groups, and to propose specific prevention measures for each actor involved.

Conclusions. There are many factors, which contributes to road crashes and related injuries, but those requires multisectoral involvement.

\section{Cuvinte cheie: FACTORII COMPORTAMENTALI ÎN PRODUCEREA TRAUMATISMELOR RUTIERE}

traume rutiere, Introducere. Traumele rutiere constituie o problemă majoră de sănătate publică, ocupând factori de risc, acci- locul 8 după principalele cauze de deces și se estimează că vor deține locul 5după cauzele de dente rutiere, prevenire. deces până în 2030. Copiii, pietonii, bicicliștii și vârstnicii rămân printre cei mai expuși riscului de accidente rutiere.

Material și metode. A fost efectuată o cercetare specializată a principalelor baze de date internaționale, precum: PubMed/MEDLINE, Google Scholar și Research Gate, urmând criteriile de includere stabilite. Datele și referințele au fost extrase și sistematizate după următoarele criterii: autor, citare, designul studiului, date obținute, limitările. Rezultatele raportate au fost compilate sub formă narativă.

Rezultate. Mulți cercetători și oameni de știință, atât din țară, cât și din străinătate, au studiat traumatismele rutiere. Autorii studiilor au folosit diferite metode și au obținut date evidente despre traumele rutiere și factorii de risc major. Printre principalele cauze ale traumelor rutiere au fost subliniate viteza excesivă, consumul de alcool și de droguri în timpul conducerii, supraoboseala, nerespectarea regulilor de circulație. Există o tendință în creștere a traumelor rutiere în rândul copiilor, iar majoritatea accidentelor rutiere cu implicarea lor au loc în lunile mai-septembrie, între orele 11.00 și 18.00. Datele obținute ne motivează să continuăm studiul acestui subiect mai în profunzime, pe grupe de vârstă separat și să întreprindem măsuri de prevenire specifice pentru fiecare actor implicat.

Concluzii. Există mulți factori care contribuie la producerea accidentelor rutiere și a traumelor rezultate de pe urma acestora, dar acestea pot fi prevenite cu eforturi multisectoriale comune. 


\section{INTRODUCTION}

Road injuries are a widespread public health problem, particularly in low- and middle-income countries, and are responsible for more years of life lost than most of human disease (1-3). This public health problem is widespread and has social and economic sequelae (4) that can influence the development and stability of countries. The negative social and economic impacts are very high for the people affected, their families, and the country as a whole. According to World Health Organization (WHO), Global Status Report on Road Safety, the number of deaths on the world's roads remains unacceptably high, with an estimated 1.35 million people dying each year $(2,5)$. Road traffic injuries are now the leading cause of death for children and young adults aged 5-29 years and more than half of all road traffic deaths are among vulnerable road users: pedestrians, cyclists, and motorcyclists (2). The Global Burden of Disease Collaborative Network, 2019, estimates that road injury ranks 8th after the main causes of death and according to forecasts will rank 5 th by 2030 .

The aim of this literature review was to identify the main behavioral risk factors responsible for the road traffic injuries among adult population and develop prevention measures for road safety among the target group. The PICO tool (population, intervention, comparison, outcome) was used to formulate the research question of the study: Would identifying and assessing the risk factors for road traffic injuries among populations above 18 years old contribute to the development of specific actions in changing the risky behavior and reduce road injury indicators?

\section{MATERIAL AND METHODS}

A specialized literature search was conducted within the main international databases, including: PubMed/MEDLINE, Google Scholar, and Research Gate. The search was done by applying Boolean operators: road trauma AND accident, road trauma AND risk factors, "road trauma" AND "risk factors", (trauma OR risk factor), car accident. Considering the significant amount of information published on the topic, the search was assigned for the period of 2010-2021. The inclusion criteria were the following: studies related to motor vehicle crashes and risk factors, original research, observational studies and systhematic reviews, full-text articles, written in
English and published in open access, all of those criteria referring to population above 18 years old. From the 4535 results obtained from the applied operators, only 45 studies were included in the review, which answered the specific set up-criteria. Most of the articles were excluded because they were not published in open access and another majority were excluded because the study population was under 18 years old. Also excluded the book chapters, papers/abstracts presented at conferences and articles not related to behavioral risk factors in road traffic injuries. Data and references were extracted systematically into results tables, which included: author/citation, study design, assessments/data, limitations, and key facts. Reported outcomes were compiled in narrative form.

\section{RESULTS}

According to the results of the current study, behavioral risk factors have a great importance in road traffic injuries $(2,3,6,7)$, associated with road infrastructure, environmental factors, and factors conditioned by the vehicle $(8,9)$. In the literature, varied behavioral factors are described that contribute to the prevalence of road traffic crashes and injuries. According to the World Health Organization's Global Road Safety Report (2) the most common causes of road trauma are traffic rule violations, drunkenness, poor road conditions, and environmental factors (e.g., ice, fog, technical vehicle defections, time of year, street lighting). Other important contributing factors include: age, sex, road safety knowledge and skills, and proper use of the safety device. A paper regarding human-centered crash contributing factors on crash outcomes (7) identified six specific driving behaviors considerably contributing to the prevalence of serious crashes: driver error, speeding, driving under the influence, fatigued driving, distracted driving, and not using a seatbelt.

A recent study (10) conducted in Nigeria on 321 individuals involved in road traffic crashes highlighted four major contributing behaviors of road users, such as not using seat belts, driving under the influence of alcohol, using a mobile phone while driving, and not using child restraint systems. Approximately $64 \%$ did not use seat belts, which was associated with young people and being alone in the vehicle. They also noted that the level of education and driving 
experience affected the rate of seat belt compliance, the higher the level of education and more years of experience behind the wheel both increased the use of seat belts. About $1 / 3$ of road users admitted to driving under the influence of alcohol and more than half admitted to not using child restraint systems.

Two of the most identified important factors for road safety are lack of attention and distraction of drivers, by writing text messages on the phone, or by looking at roadside billboards (11). Driver distraction has a high impact on safety, and has been estimated that $25 \%$ of crashes involve at least some degree of distraction of traffic participants (12-15) and about $68 \%$ of crashes were caused by distraction (16). Distracted driving is also classified by the WHO $(14,17)$ as an important risk factor for road traffic crashes (18), with behaviors including mobile phone use, eating, talking with passengers, personal care, reading, watching videos, adjusting the radio or music player, and using a Global Positioning System (GPS) for navigating locations.

Examining the causal effects of distracted driving on the severity of traffic crashes, the results of another study indicate that drivers are more likely to be young and female and distracted on roads with higher speed limits, during rush hour, at intersections, during sunlight, during cloudy weather, and driving heavy vehicles. Results have also shown significant effects of driver distraction on the severity of traffic crashes, highlighting the need for countermeasures to reduce distracted driving (19).

Driver distraction according to a recent scientific report, can be both internal and external. The presence of external sources (e.g., billboards, advertising, other ongoing events, urbanization) $(20,21)$ are not in the driver's control, whereas internal sources are frequently self-imposed and avoidable.

Within the main distracting behaviors is also, mobile texting and calls, talking to passengers, handling children, smoking, and looking at roadside advertisements (whether it is directly on the roadside or elevated). Gazder et al. 2020, split the road distraction into three main types: manual distraction, visual distraction, and cognitive distraction (22).

Driver emotions (e.g., anger) are also associated with road injuries, resulting in both positive and negative driving behavior, such as high speed, distraction, and noncompliance with the traffic rules. A study on this issue in Japan reveled that drivers' negative emotions (angry and sad) are likely to increase driving speed (23).

According to the European transport safety council (24), driving under the influence of alcohol is one of the four main killers on the road, alongside speeding, non-use of seatbelts, and driver distraction. Driving under the influence of alcohol, drugs, and fatigue, were analyzed in the European Survey of Road users' safety Attitudes (ESRA) study to underline their impact (25). According to the WHO, $27 \%$ of road traffic deaths worldwide are attributable to alcohol (2, 26). Alcohol is the most commonly used psychoactive substance among drivers in Europe (27).

A recent study performed in Brazil (28) and one of the largest and longest studies ever developed for monitoring road traffic risk factors, highlighted that alcohol-related fatalities were consistently a high percentage, with $39 \%$ of road traffic deaths involving alcohol in 2016. However, the authors indicate it is a great challenge for the public authorities to control drink driving and speeding behavior. Nevertheless, the driving rate under the influence of alcohol has decreased, likely due to an increase of drivers who refuse breath alcohol tests, while the speeding rates remain high especially for motorcyclists.

Despite countries having implemented legal blood alcohol concentration (BAC) limits (2), many alcohol-related crashes and injuries continue to be registered. Around $31 \%$ of all road crashes in the US, around $34 \%$ in China (29), and over a third of car driver fatalities in Australia attributable to illegal alcohol consumption (30). About one-quarter of those road user fatalities were impaired by either alcohol or drugs according to a recent study that presents detailed statistics on alcohol and drug findings among active road users (27).

A recent study in Australia on drink-driving behaviors comparing data during and after the period of COVID-19 restrictions, found that young males were more likely to drink-drive during restrictions (31).

Another important behavioral risk factor associated with motor vehicle crashes is aggressive 
and anger-related driving. One study highlights the importance of understanding and preventing aggressive driving and its negative results to reducing the number of crashes (32).

One of the main causes of road traffic crashes and a growing phenomenon is the use of mobile phones while driving a car. Despite legislative restrictions in most countries of the world, many drivers continue to use their mobile phones while driving, putting their lives, passengers, and pedestrians at risk (15). Use of mobile phones while driving is common in such countries as Sweden, Australia, the United States, the United Kingdom, and Spain $(14,17)$. Almost two-thirds of drivers in high-income countries admit to using their cellphones at some time while driving (33). One study simultaneously analyzed the knowledge, attitudes, and behavior towards the use of mobile phones while driving in Naples, one of the largest and most populous metropolitan areas in Italy. They highlighted that $69 \%$ of respondents have used their mobile phone while driving at least once in their lifetime, $63.6 \%$ have made phone calls while $75.2 \%$ only answer them while driving; $49.1 \%$ read messages and only $33.3 \%$ write them while driving, $34.1 \%$ do not stop to answer a call and only $10 \%$ do not value the use of headsets while driving as fundamental (34). According to the findings of a recent study in the US (35), mobile phone use while driving increases crash risk by four times compared to those who do not use mobile phones.

Drivers' propensity to use a mobile phone while driving was examined by the type of road given, the condition of the road, and the nature of the traffic through an observational study (36). Results of that study showed a high percentage of drivers did not use their phone on highways, bumpy roads, and in low-density traffic, while most drivers used their mobile phones on streetlevel roads, and smooth surface roads. They also found determining factors in answering calls during driving were based on the urgency of the call, the exigency of the calls, and the speed limit of the roadway.

Crash risk factors related to age and sex have long been recognized in the literature. Young people have an increased risk of traffic crashes and this risk tends to decreas as they age and gain more driving experience. Young men are more frequently involved in road traffic crashes, compared to young women and older drivers. However, women have a higher risk of injury and hospitalization when involved in a crash. $(2,37$, 38). Overall, young adults have been found to have higher rates of texting and driving than older drivers (18). In the U.S., teen drivers are at considerable excess risk of motor-vehicle crashes compared with adult drivers and there are several factors which lead to crashes (39): conversations with passengers in the car; night and weekend driving have higher crash risk for all ages but more associated with younger drivers; drinking and driving; and not using the seatbelt. Compared to other age groups, teens have the highest rates of not using a seatbelt. According to another study, young drivers are also more likely to use mobile phones while driving compared to older people. The proportion of crashes involving young people is exceedingly high (29). Knowledge, skills, and experience of the driver also are of interest, young drivers, especially novice ones, are more likely to be involved in crashes compared to experienced drivers (18). Factors such as previous driving violations, distraction, passenger presence, time of crash, and lack of driver protection system have been highlighted as predominant risk factors in multiple young drivers of different ages (40). Other studies underline that more middle-aged drivers use mobile phones while driving, compared to elderly drivers (41). A study in Jordan also found that drivers with more driving experience were more exposed to crash risk and were often involved in crashes (4). The authors of an analytic study in Portugal (42), identified that 612 car drivers $(37.3 \%)$ reported being involved in a road traffic crash with damage or injury in the period 20132016. The majority were male, older than 65 years old, with no children, not employed, and living in an urban area.

In most studies, the authors came up with solutions to contribute to the prevention of road injuries. One of the solutions is to set up intelligent transportation systems, such as speed limit systems (43) with new methods and strategies for managing speed limits that can effectively accommodate high traffic densities to increase road safety. Car-sharing software (e.g., the DiDi travel app) can help to decrease driving distractions and improve the driver's ability (44). Applying different theories of behavior change (18) or examining virtual reality driving simulations 
(ex. determining the effect of cell phone position) (33) could contribute to more effective measures in road safety control. Other smart technologies, such as the Cab Safety Device driver monitoring systems, could identify driver sleepiness or fatigue (45). It is also valuable to evaluate existing road safety policies and practices (46) and update them to follow best practice.

\section{CONCLUSIONS}

1. There are many factors that contribute to road crashes and related injuries, which require a multisectoral involvement. Considering the burden and impact of traffic crashes and injuries, more road safety campaigns should be launched, initiated, and supported and strategic road safety management mechanisms should be developed and implemented to control and reduce the growing number of crash rates.

2. Results from this review further motivate the need to study this topic in depth, concentrating specifically on each of the risk factors identified. In particular, further research on separate age groups and development of specific prevention measures are required.

\section{CONFLICT OF INTERESTS}

All authors declare no competing interests.

\section{REFERENCES}

1. Heydari S, Hickford A, McIlroy R, Turner J, Bachani AM. Road Safety in Low-Income Countries: State of Knowledge and Future Directions. Sustainability. 2019; 11(22):6249. doi:10.3390/ su11226249

2. WHO (World Health Orgainisation). Global Status Report on Road. World Heal Organ. 2018;20. Available from: http://apps.who.int/bookorders (Accessed 22 June 2021).

3. Petridou E, Moustaki M. Human Factors in the Causation of Road Traffic Crashes. European Journal of Epidemiology. 2000;16(9):819-26. Available from: http://www.jstor.org/stable/3581952 (Accessed 22 June 2021).

4. Jadaan K, Albeetar N, Abuhalimeh D, Naji Y. Analysis of driver behavior in Amman using Manchester Driver Behavior Questionnaire. Acta Technica Jaurinensis. 2021. doi:10.14513/actatechjaur. 00599

5. Evans L. Death in Traffic: Why Are the Ethical Issues Ignored? Studies in Ethics, Law, and Technology. 2008; 2(1). doi:10.2202/1941-6008.1014

6. Adanu E.K, Jones S. Effects of Human-Centered Factors on Crash Injury Severities. Journal of Advanced Transportation. 2017; 1-11. doi:10.1155/ 2017/1208170

7. Rankin KA, Zaki T, Ou D, Kim CY, Averbukh L, Maisano JR, et al. High-risk motor vehicle drivers engage in more risk behaviors than motorcyclists. Sicot-J. 2021;7.

8. Cociu S. Environmental risk factors related to road traffic crashes. Arta Medica. 2020;4(77):937. Available from: http://repository.usmf.md/ bitstream/20.500.12710/14180/1/Factorii_De_ Mediu_Care_Influenteaza_Producerea.pdf (Accessed 19 June 2021).

9. Sawin J, Martinot E, Appleyard D. Global Status
Report. Renew Energy World. 2010;13(5):24-31. Available from: http://ra.ocls.ca/ra/login. aspx? url=http://search.ebscohost.com/login. aspx?di rect $=$ true $\& d b=e n r \& A N=56097888 \&$ site $=$ ehost live (Accessed 1 July 2021).

10. Uhegbu UN, Tight MR. Road user attitudes and their reported behaviours in Abuja, Nigeria. Sustain. 2021;13(8).

11. Vrkljan J, Jeleč V. Research on the influence of roadside billboards on cognitive workload of young drivers and traffic safety. Teh Vjesn. 2021;28(2):488-94.

12. Curry DG. In-vehicle cell phones: Fatal distraction - Yes or no? Proc Hum Factors Ergon Soc. 2001; (March):562-6.

13. Stutts J, Reinfurt D, Staplin L, Rodgman E. The Role of Driver Distraction in Traffic Crashes. AAA Found. Traffic Saf. 2001.

14. Geneva. (n.d.). A Growing Problem Of Driver Distraction 2011 WHO Library Cataloguing-inPublication Data Contentsts. World Health Organization. Available from: http://www.who.int/vi olence_injury_prevention/publications/road_trac /en/index.html (Accessed 3 July 2021).

15. Lipovac K, Đerić M, Tešić M, Andrić Z, Marić B. Mobile phone use while driving-literary review. Transportation Research Part F: Traffic Psychology and Behaviour. 2017;47:132-142. doi:10.1016/ j.trf.2017.04.015

16. Otto J, Finley K, Ph D, Mcmahill A, Arpin J. Guidance to Promote Family Rules and Workplace Policies to Reduce Cell Phone Use While Driving and Promote Engaged Driving, Task 2 Report, 2021. Available from https://www.mdt.mt.gov/other/ wedta/external/research/docs/research_proj/ts c/ENGAGED_DRIVING/TASK_2_REPORT.pdf (Accessed 1 July 2021). 
17. Driver Distraction. CRC Press. 2008. doi:10.1201/ 9781420007497

18. Udaya Shankar BS, Tyagaraju MR, Sujatha PL, Shivakumar BC, Disha SN, Prerana C. Comparison of Knowledge, Attitude and Practice Regarding Usage of Mobiles During Driving amongst Medical and Engineering Students Aged 18-21 Years in Bengaluru North. Medico Legal Update. 2021; 21(2):1216-23. doi:10.37506/mlu.v21i2.2856

19. Guopeng Zhang, Qi Liang, Xinguo Jiang, ShengdeYang, Yingfei Fan, Xin Qiu, Tangwei Yao CM. Examining the causal effects of distracted driving on crash injury severities. J Transp Saf Secur. doi: 101080/1943996220211923102. 2021

20. Lym Y, Kim S, Chen Z. The influence of urbanicity and built environment on the frequency of distracted driving-related crashes: a multi-state comparison. Int J Urban Sci. 2021;0(0):1-28. doi:10.1080/12265934.2021.1946418

21. Oviedo-Trespalacios 0 , Truelove V, Watson B, Hinton JA. The impact of road advertising signs on driver behaviour and implications for road safety: A critical systematic review. Transp Res Part A Policy Pract. 2019;122:85-98. doi:10.1016/ j.tra.2019.01.012

22. Gazder U, Assi KJ. Determining driver perceptions about distractions and modeling their effects on driving behavior at different age groups. J Traffic Transp Eng. 2021;1-11. doi:10.1016/j.jtte. 2020.12.005

23. Kadoya Y, Watanapongvanich S, Khan MSR. How is emotion associated with driving speed? A study on taxi drivers in Japan. Transp Res Part F Traffic Psychol Behav. 2021;79:205-16. doi:10.1016/j.trf. 2021.04.020

24. ETSC. Progress in reducing drink driving in Europe. 2018;(February):28 M4-Citavi. Available from: www.etsc.eu/smart (Accessed 10 July 2021).

25. Apostolos Z, Athanasios T, Laiou A, Michelaraki E. Examining the relationship between impaired driving and past crash involvement in Europe: Insights from the ESRA study. Int J Inj Control Saf Promot 2021. doi:101080/1745730020211928234

26. Le Daré B, Degremont A, Couty C, Baert A, Bouvet $\mathrm{R}$, Morel I, et al. Alcohol and drug consumption among motor vehicle drivers in the Brittany region of France: A 9-year cross-sectional population study. Prev Med Reports. 2021;23:101454.

27. Lacey JH, Kelley-Baker T, Berning A, Romano E, Ramirez A, Yao J, et al. Drug and Alcohol Crash Risk: A Case-Control Study. Report No. DOT HS 812 355. Washington, DC: National Highway Traffic Safety Administration, 2016.

28. Andreuccetti G, Leyton V, Carvalho HB, Sinagawa DM, Bombana HS, Ponce JC, et al. Drink driving and speeding in Sao Paulo, Brazil: Empirical cross-sectional study (2015-2018). BMJ Open. 2019;9(8):1-8.

29. Zhao X, Zhang X, Rong J. Study of the effects of alcohol on drivers and driving performance on straight road. Mathematical Problems in Engineering. 2014. doi:10.1155/2014/607652

30. Government of South Australia. Alcohol and Drugs in Road Crashes in South Australia. Dep Planning, Transp Infrastruct. 2016;1:1-7. Available from: https://www.who.int/violence_injury_ prevention/road_safety_status/2018/en/ (Acessed 10 Iuly 2021).

31. Watson-Brown N, Truelove V, Parker E, Davey J. Drink driving during the COVID-19 pandemic. Transportation Research Part F: Traffic Psychology and Behaviour. 2021;78:369-80. doi:10. 1016/j.trf.2021.02.020

32. Seyed Iman Mohammadpour HN. Aggressive driving: Do driving overconfidence and aggressive thoughts behind the wheel, drive professionals off the road? Transp Res Part F: Traffic Psychol Behav. 2021;79:170-184.

33. Turnbull PRK, Khanal S, Dakin SC. The effect of cellphone position on driving and gaze behaviour. Scientific Reports. 2021;11(1):1-10. doi:10.1038/ s41598-021-87120-2

34. Montuori P, Sarnacchiaro P, Nubi R, Di Ruocco D, Belpiede A, Sacco A, De Rosa E. The use of mobile phone while driving: Behavior and determinant analysis in one of the largest metropolitan area of Italy. Accid Anal Prev. 2021;157106161. doi:101016/j.aap2021106161

35. Farmer CM, Braitman KA, Lund AK. Cell phone use while driving and attributable crash risk. Traffic Injury Prevention. 2010; 11(5):466-470. doi:10.1080/15389588.2010.494191

36. Olapoju Om. Road Characteristics, Traffic Nature and Drivers' Propensity To Use Mobile Phone. Analele Univ din Oradea, Ser Geogr. 2021; 31(1):37-44.

37. Cullen P, Möller H, Woodward M, Senserrick T, Boufous S, Rogers K, et al. Are there sex differences in crash and crash-related injury between men and women? A 13-year cohort study of young drivers in Australia. SSM - Popul Heal. 2021;14.

38. Shaaban K. Impact of Experience and Training on Traffic Knowledge of Young Drivers. The Open Transportation Journal. 2021;15(1):61-8. doi:10. 2174/1874447802115010061

39. Moore TJ, Morris T. High-risk teen driving : Targeted restrictions can deliver large safety improvements. 2021. Available from: https://tod dmo rris.net/wp-content/uploads/2021/04/Mo ore_Morris_2021-1.pdf (Accessed 10 Iuly 2021).

40. Rahman MA, Hossain MM, Mitran E, Sun X. Understanding the contributing factors to young driver crashes: A comparison of crash profiles of 
three age groups. Transp Eng. 2021;5:100076. doi:10.1016/j.treng.2021.100076

41. Trisko J, Ferraro FR. Younger and Older Adults' Opinions on Driver Distractions and Potential Cellular Phone Laws. Psychological Record. 2014; 64(3):503-507. doi:10.1007/s40732-014-0037-8 Bon de Sousa T, Santos C, Ceu M, Areal A, Trigoso J. Road traffic accidents and self-reported Portuguese car driver's attitudes, behaviors, and opinions: Are they related? Traffic Inj Prev. 2016;17(7)705-11. doi:101080/1538958820161150591

42. Bon de Sousa T, Santos C, Ceu M, Areal A, Trigoso J. Road traffic accidents and self-reported Portuguese car driver's attitudes, behaviors, and opinions: Are they related? Traffic Inj Prev. 2016;17(7)705-11. doi:101080/1538958820161 150591

43. Al-harbi AO, Jamjoom AA. Analysis Of Drivers
Attitude To Variable Speed Limit Systems On Multi-lane Highways. MECSJ. 2021;43. Available from: https://www.mecsj.com/uplode/images/photo/ Analsis_Of_Drivers_Attitude_To_Variable_Speed_L imit_Systems_On_Multi-lane_Highways_.pdf (Accessed 10 Iuly 2021).

44. Jing C, Zhi J, Yang S, Wang W. Impact of Driver Age and Experience in Software Usage on Driving Safety and Usability of Car-Sharing Software. 2021. doi:10.1155/2021/6633379

45. Vinodhini V, Abishek M, Divya K. A Behavioral Approach To Detect Somnolence Of Cab Drivers Using Convolutional Neural Network. Ictact journal on soft computing. 2021;11(03). doi:10. 21917/ijsc.2021.0337

46. Williamson A. Why do we make safe behaviour so hard for drivers? Journal of Road Safety. 2021;32(1):24-36. doi:10.33492/JRS-D-20-00255

Date of receipt of the manuscript: $21 / 07 / 2021$

Date of acceptance for publication: 18/09/2021

Svetlana COCIU, ORCID ID: 0000-0001-8209-815X

Olga IONCU, ORCID ID: 0000-0002-8617-4559

Camelia CAZACU-STRATU, ORCID ID: 0000-0003-4529-966X

Serghei CEBANU, ORCID ID: 0000-0002-2493-4882, SCOPUS Author ID: 57220030355

Cara HAMANN, ORCID ID: 0000-0001-8916-7285, SCOPUS Author ID: 36537136400 